\title{
Covid-19: Predictors of Depression and Anxiety Among High School Students
}

\author{
Covid-19: Lise Öğrencilerinde Depresyon ve Anksiyetenin \\ Prediktörleri
}

\author{
Neşe Yakşi ${ }^{1}$, Mehtap Eroğlu², Mikail Özdemir ${ }^{3}$
}

\begin{abstract}
:
Although it is thought that Coronavirus Disease 2019 (COVID-19) infection does not clinically affect children as severely as adults, the short and long-term psychological effects on adolescents during the COVID-19 pandemic are quite significant. The aim of the present study is to determine the prevalence of anxiety and depression and related factors in high school students during the COVID-19 pandemic. In June and July 2020, 506 high school students from two different provinces were included in the present study. A questionnaire form including sociodemographic characteristics, 'Child Depression Scale' and 'State-Trait Anxiety Scale' were applied online. Univariate and multivariate analyzes were used in data analysis, and $\mathrm{p}<0.05$ was accepted as significance level. Depression prevalence was $22.9 \%$, median trait anxiety score was 44 , and median state anxiety score was 39 . Low-income level, think of themselves or the household was at risk, using information sources other than health professionals, high screen time, high mother coronavirus stress score and low family communication score were shown to increase depression. Higher school grades, not regularly exercising, think of themselves or the household were at risk, staying alone at home, high mother's and father's coronavirus stress scores and low family communication score were shown to increase state anxiety. Adolescents highly suffer from psychological outcomes of the COVID-19 pandemic. It is essential to involve the family in planning and implementing early mental health interventions during the pandemic, especially as parent-related factors affect children's psychological state. During the social isolation period, it is recommended to organize indoor exercise programs for children and adolescents, limit the time spent in front of the screen, and improve communication with family members.
\end{abstract}

Keywords: COVID-19 Pandemic, Depression, Anxiety, Adolescent, Turkey

${ }^{1}$ MMed., Nigde Central Community Health Center, Public Health, Nigde-Turkey,Orcid İd: https://orcid.org/ 0000-0002-6175-2359

${ }^{2}$ MMed, Nigde Training and Research Hospital, Child and Adolescent Psychiatry, Nigde-Turkey, Orcid İd: https://orcid.org/ 0000-0002-58799412

${ }^{3}$ MMed., Oguzeli District Health Directorate, Public Health, Gaziantep-Turkey,Orcid İd: https://orcid.org/ 0000-0001-7567-1763

Address of Correspondence/Yazışma Adresi: Nigde Central Community Health Center, Public Health, Nigde-Turkey, E-mail: drnsyks@gmail.com

Date of Received/Geliş Tarihi: 31.03.2021, Date of Revision/Düzeltme Tarihi: 02.06.2021, Date of Acceptance/Kabul Tarihi: 14.07.2021, Date of Online Publication/Çevirimiçi Yayın Tarihi: 01.09.2021

Citing/Referans Gösterimi: Yakși. N., Eroğlu, M., Özdemir, M. (2021). Covid-19: Predictors of Depression and Anxiety Among High School Students, Cyprus Turkish Journal of Psychiatry \& Psychology, 3(3): 192-202

C 2021 The Author(s). Published by Cyprus Mental Health Institute / Cyprus Turkish Journal of Psychiatry and Psychology (www.ktppdergisi.com). This article is an open access article distributed under the terms and conditions of the Creative Commons Attribution 4.0 license which permits use, sharing, adaptation, distribution and reproduction in any medium or format, provided the original work is properly cited and is not used for commercial purposes. http://creativecommons.org/licenses/by/4.0/ 


\section{Öz:}

Koronavirüs Hastalığı 2019 (COVID-19) klinik olarak çocukları erişkin bireyler kadar etkilemese de COVID-19 pandemisinin adölesanlar üzerindeki kısa ve uzun dönem etkileri oldukça önemlidir. Bu çalışmanın amacı COVID19 pandemisinde lise öğrencilerinin depresyon ve anksiyete sıklığ 1 ile etkileyen faktörlerin belirlenmesidir. Çalışmaya Haziran-Temmuz 2020 tarihlerinde 2 farklı ilden 506 lise öğrencisi dahil edilmiştir ve sosyodemografik özellikleri içeren bir soru formu, 'Çocuk Depresyon Ölçeği' ve 'Durumluk-Sürekli Anksiyete Ölç̧eği' online olarak uygulanmıştır. Veri analizinde tek değişkenli ve çok değişkenli analizler uygulanmış olup $p<0.05$ anlamlılık düzeyi olarak kabul edilmiştir. Depresyon sıklığ $\% 22.9$, sürekli anksiyete ölçek puanı ortanca değeri 44, durumluk anksiyete ölçek ortanca değeri 39 olarak bulunmuştur. Düşük gelir düzeyi, kendinin ya da aynı evde yaşadığı kişilerin risk altında olduğunu düşünme, bilgi kaynağı olarak sağlık profesyonelleri dışındaki kaynakların kullanılması, uzamış ekran süresi, koronavirüsle ilgili anne stres puanının yüksek olması, aile içi iletişim puanının düşük olmasının depresyon sıklığını artırdığı gösterilmiştir. Daha yüksek okul sınıfı, düzenli egzersiz yapmama, kendinin ya da aynı evde yaşadığı kişilerin risk altında olduğunu düşünme, evde yalnız kalma, koronavirüsle ilgili anne ve baba stres puanının yüksek olması ve aile içi iletişim puanının düşük olmasının anksiyete puanını artırdığı gösterilmiştir. Adölesanlar COVID-19 pandemisinin psikolojik sonuçlarından oldukça muzdariptir. Özellikle ebeveyn ilişkili faktörlerin çocukların psikolojik durumunu etkilediği görüldüğünden, pandemide erken ruh sağlığı müdahalelerinin planlanması ve uygulanmasında ailenin dahil edilmesi önemlidir. Sosyal izolasyon döneminde çocuk ve ergenler için ev içi egzersiz programlarının düzenlenmesi, ekran başında geçen sürenin kısıtlanması, aile bireyleri ile iletişimin iyileştirilmesi önerilmektedir.

Anahtar Kelimeler: COVID-19 Pandemisi, Depresyon, Anksiyete, Adölesan, Türkiye

\section{Introduction}

In December 2019, a pneumonia outbreak associated with a novel coronavirus called SARS-CoV-2 was reported in China. The World Health Organization named the disease caused by the new coronavirus as Coronavirus Disease 2019 (COVID-19) on 12th February 2020 (WHO, 2020). COVID-19 has spread worldwide and was declared a pandemic by the World Health Organization on 11th March 2020.

Epidemics have psychosocial effects on individuals and societies at various dimensions and forms. Illness and death anxiety, feelings of helplessness, and fear of stigma experienced during epidemics can trigger a mental collapse (Hall, Hall and Chapman, 2008). An epidemic can trigger psychiatric symptoms in people without psychiatric illness and worsen symptoms in pre-existing psychiatric diseases. A person faced with an infectious threat is under intense psychological pressure. Data from the SARS pandemic in 2003 and the H1N1 pandemic in 2009 revealed that people were exposed to a considerable level of fear and panic, which had significant psychological consequences (Chong, 2004; Goulia, Mantas, Dimitroula, Mantis and Hyphantis, 2010). The situation is similar for the COVID-19 pandemic. During pandemic periods, significant psychiatric morbidities can range from anxiety, depression, panic attacks, somatic symptoms, and posttraumatic stress disorder to delirium, psychosis, and even suicide (Hall, 2008).

Studies conducted in the United States and Canada on COVID-19, which aroused great concern worldwide, showed that public concerns about the disease were high (Asmundson and Taylor, 2020). In the first psychological impact and mental health study conducted in the general population in China during the first two weeks of the COVID-19 pandemic, it was observed that $53.8 \%$ of the respondents were moderately or severely affected by the outbreak. Moderate to severe depressive symptoms were reported in $16.5 \%$ of the respondents, moderate to severe anxiety symptoms in $28.8 \%$, and moderate to severe stress levels in $8.1 \%$ (C. Wang, Pan, Wan, Tan, Xu, Ho, 2020).

In order to mitigate the risks and effects of the disease, many areas of life have been affected by the pandemic, such as the suspension of educational activities, the canceling of sports competitions, physical restrictions in social communication, stopping or slowing down economic activities, being unemployed or having to work despite isolation measures, and postponing court hearings (Malay, 2020). Such sudden changes in daily life are thought to be risk factors that can significantly affect mental health. Although the disease is brought partially under control by time and there is a partial relief throughout the world with the new normalization process, it is possible that the stress experienced may have already caused mental problems (Atrooz, Liu and Salim, 2019).

Although children are reported to be less susceptible to COVID-19 infection, it is thought that as a result of the closure of schools and playgrounds and the restriction of outdoor activities due to fear of contamination, the epidemic had an indirect effect on children and triggered anxiety symptoms such as panic attacks and psychosomatic symptoms (Tsamakis, 2020). The epidemic's short and long-term psychological effects on children and adolescents are important considering that they constitute $42 \%$ of the world population (Dalton, Rapa and Stein, 2020).

A review of 63 studies found a significant relationship between loneliness and mental health problems in children and adolescents. Loneliness was associated with future mental health problems until nine years later. The strongest relationship was with depression (Loades, 2020). In a study conducted in Turkey, schools and home quarantine closure during the COVID-19 pandemic caused anxiety and loneliness in young people (Kilincel, Kilincel, Muratdagi, Aydin and Usta, 2020). 
While pandemic measures are certainly necessary, prolonged school closure and home quarantine during a pandemic may affect children's physical and mental health. Evidence suggests that when children are not in school (e.g., weekends and summer vacations), they are physically less active, their screen times are much longer, and their sleep patterns are irregular (Brazendale, 2017; G. Wang, 2019). In addition, a long duration of isolation, fear of infection, insufficient knowledge about the disease, decreased social relations, and financial losses in the family were associated with more negative consequences on children and adolescents (Brooks, 2020).

Psychological reactions such as maladaptive behaviors, emotional distress, and defense reactions may occur during pandemic periods (Taylor, 2019). Restrictive measures such as quarantine, isolation, and social distancing impact the emotional response to the pandemic and psychological welfare. Mass quarantine practices can significantly increase fear for many reasons (Rubin and Wessely, 2020).

Psychological interventions and social support can effectively reduce the symptoms of depression and anxiety during or after stressful events (Purgato, 2018). Based on the experience from previous global pandemics, the development and implementation of mental health assessment, support, and treatment services are significant and immediate goals in the COVID-19 pandemic (Xiang, 2020). Studies demonstrated that individuals who experience public health emergencies have varying degrees of stress disorders even after the emergency is over, and these individuals should not be ignored (Duan and Zhu, 2020).

Surveillance of the psychological consequences of lifethreatening diseases that have epidemic potential as well as preparation for early mental health interventions must become a routine practice worldwide. It is also important to address psychological factors to understand and manage the emerging responses and behaviors during a pandemic.

This study aims to determine the prevalence of anxiety and depression and related factors in high school children during the COVID-19 pandemic.

\section{Material and Method}

\section{Participants and Procedures}

The present study is a cross-sectional study. We planned to include all Health Vocational High School students, Science High School, and Sports High School in Nigde and Health High School, and Science High School in Osmaniye. The total number of students in these schools was 1325 . The sample size was calculated to be 577 (event frequency $25 \%$, error margin $5 \%$, design effect 2.0 , and confidence interval 95\%) using the Open-epi program. Considering a 20\% refusal rate, we planned to reach 692 students. Stratification was made according to the number of students at each grade of each school. A total of 506 students were reached. The study data was collected online between 8th June 2020 and 31st July 2020 using the Google Forms application. Before the online survey, informed consent was obtained. After the sociodemographic questionnaire consisting of 24 questions, the 'Children's Depression Inventory' and the State-Trait Anxiety Inventory (STAI) were applied. Consent from the Local Ethics Committee (Decision No:
2020/05-14) and permissions from Provincial Directorates of National Education were obtained.

\section{Survey Instrument}

\section{Children's depression inventory}

It was developed by Kovacs in 1981 (Kovacs, 1981). This scale, which was developed based on the Beck Depression Inventory, can be applied to children and adolescents between the ages of six to seventeen and consists of 27 items. It is a self-rating scale that evaluates the last two weeks. Answers given in each set of three sentences are scored between 0 and 2 . The sum of these scores gives the depression score. The validity and reliability study of the Turkish version of the scale was performed, and the cutoff score was determined as 19 points (Oy, 1991).

\section{State-trait anxiety inventory (STAI)}

It was developed in 1970 by Spielberger et al. (Spielberger, 2010). It was adapted to Turkish society in 1985 by Oner and Le Compte (Oner and Le Compte, 1998). It is a Likert-type scale that separately measures state and trait anxiety levels with 20 questions. The total score obtained from both scales varies between 20-80. High scores indicate higher anxiety levels. It is a fourdegree scale ranging from "Not at all" to "Very much so". There are two types of expressions in the State-Trait Anxiety Inventories. Direct expressions state negative feelings, while reversed expressions state positive feelings. After the total weights of the direct and reversed expressions are found, the total weight score of the reverse expressions is subtracted from the total weight score obtained for the direct expressions. A predetermined and constant value is added to this number. This constant value is 50 for the State Anxiety Inventory and 35 for the Trait Anxiety Inventory. The last value obtained is the individual's anxiety score.

\section{Statistical Analysis}

Epi Info program (Centers for Disease Control and Prevention, Atlanta) was used for statistical analysis. Frequency and percentage were given as descriptive statistics. The Chi-square test and Fisher's Exact Test were used for the analysis of categorical variables.

The Mann-Whitney U test and the Kruskal-Wallis test were used for the analysis as the continuous variables were not normally distributed.

Binary Logistic Regression analysis was used for multivariable data analysis. STAI-State and STAI-Trait Inventory scores were transformed to categorical variables by the median split method, and multivariate analysis was performed.

\section{Results}

\section{Sociodemografic Characteristics}

A total of 506 high school students from Nigde and Osmaniye provinces participated in this study. Among the students, $64.9 \%(n=328)$ were living in Nigde, and $60.7 \%$ were female. The percentage of participants from Science High School (31.6\%), Health Vocational School (35.6\%), 
and Sports Vocational High School (32.8\%) were similar. At least one of the parents was healthcare professionals in
$11.3 \%$ of the students, and $14.4 \%$ of the parents lost their work.

Table 1.

Sociodemographic features of the participants

\begin{tabular}{|c|c|c|}
\hline$n=506$ & & $n(\%) *$ \\
\hline Age & & $17(14-21)$ \\
\hline \multirow[t]{2}{*}{ Sex } & Male & $199(39.3)$ \\
\hline & Female & $307(60.7)$ \\
\hline \multirow[t]{3}{*}{ School } & Science High School & $160(31.6)$ \\
\hline & Health Vocational High School & $180(35.6)$ \\
\hline & Sports High School & $166(32.8)$ \\
\hline \multirow[t]{2}{*}{ Grade } & Grade 11 or lower & $366(72.3)$ \\
\hline & Grade $12 * *$ & $140(27.7)$ \\
\hline \multirow[t]{3}{*}{ City } & Nigde & $328(64.9)$ \\
\hline & Osmaniye & $149(29.5)$ \\
\hline & Other*** & $28(5.6)$ \\
\hline \multirow[t]{2}{*}{ Mother Education Level } & Secondary school or lower & $202(40.0)$ \\
\hline & High school or higher & $304(60.0)$ \\
\hline \multirow[t]{2}{*}{ Father Education Level } & Secondary school or lower & $238(47.0)$ \\
\hline & High school or higher & $268(53.0)$ \\
\hline \multirow{2}{*}{$\begin{array}{l}\text { At Least One Parent is a Healthcare } \\
\text { Professional }\end{array}$} & Yes & $57(11.3)$ \\
\hline & No & $449(88.7)$ \\
\hline \multirow[t]{2}{*}{ Work Loss } & Yes & $73(14.4)$ \\
\hline & No & $433(85.6)$ \\
\hline \multicolumn{2}{|l|}{ Income Level } & $3000(350-150000)$ \\
\hline \multicolumn{3}{|c|}{$\begin{array}{l}* \text { Continuous variables were summarized as median (min-max). } \\
* * \text { Last grade in high school } \\
* * * \text { Having boarding education in Nigde/Osmaniye but their families are living in other cities. }\end{array}$} \\
\hline
\end{tabular}

Among the participants, $15.2 \%$ stated that they stayed alone at home every day or generally. Those who exercise at least three days a week for at least half an hour were $57.9 \%$ of the students. Eight students $(1.6 \%)$ stated that there was a coronavirus case at home. The percent of students who did not know who was at risk for coronavirus was $51.8 \%$, and $37.3 \%$ of the participants thought they or the people they live with were at risk. In $69.3 \%$ of the participants, the sources of information about coronavirus were healthcare professionals or the official site of the Ministry of Health.

\section{Level of Depression and Affecting Factors}

The prevalence of depression in this study was $22.9 \%$. The results of univariate analysis revealed that the prevalance

\section{Table 2.}

The evaluation of factors that affect depression status of the participants of depression was higher in the participants whose mothers' had lower education level $(25.9 \%)$ compared with higher $(18.3 \%)(p=0.044)$; whose fathers' had lower education levels $(26.8 \%)$ compared with higher $(19.4 \%)$ $(p=0.046)$; whose income levels were lower compared with higher $(p<0.001)$; whose parents lost their work (34.2\%) compared with those who didn't lose their work (21\%) $(p=0.013)$. Depression was also more frequent in those who usually/every day stayed alone at home ( $p=0.038$ ), who believed that themselves or the household were at risk $(p=0.034)$, and whose information sources were other than the Ministry of Health and healthcare professionals $(p=0.004)$. Other factors that affect depression in participants are shown in Table 2. 


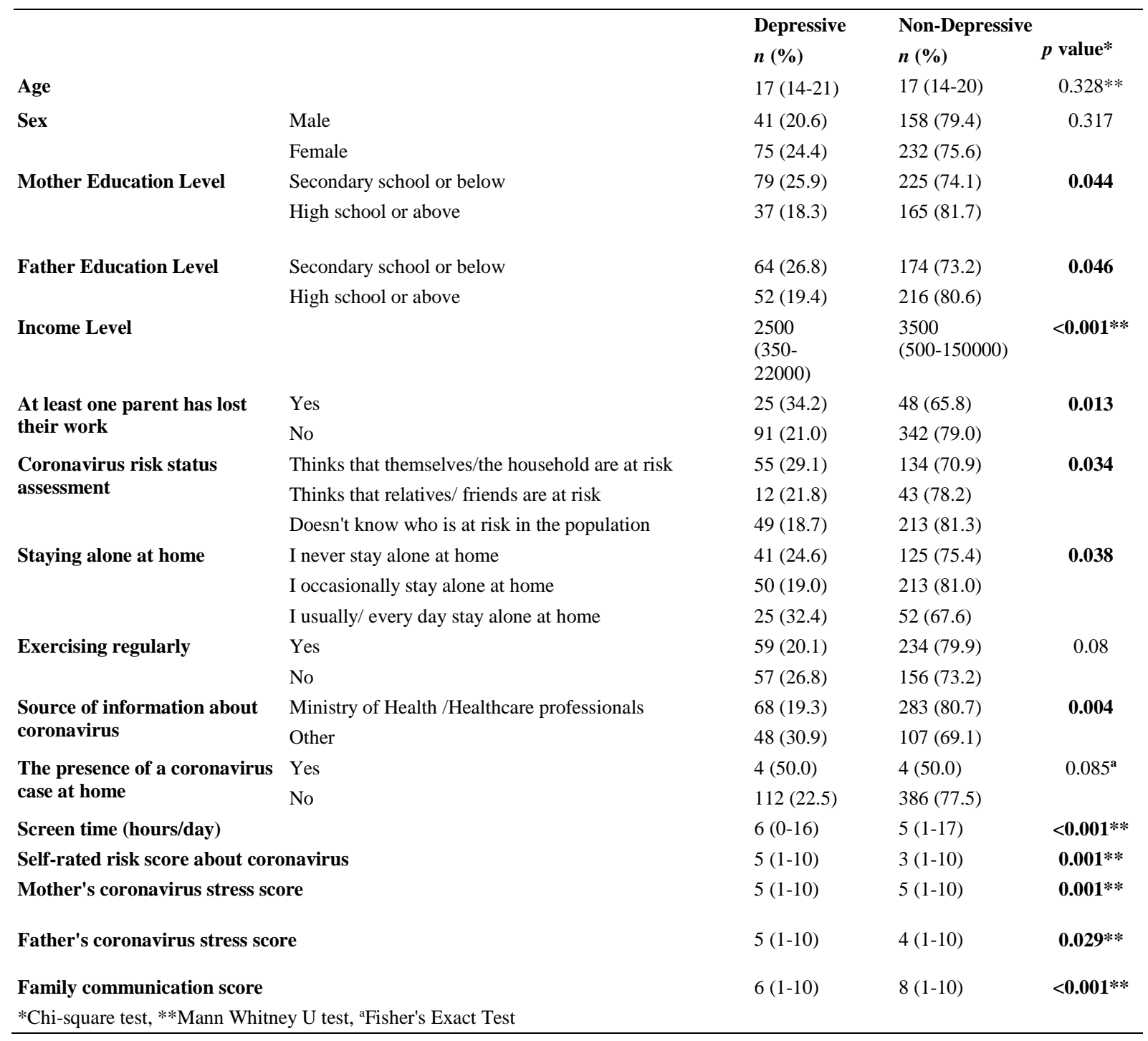

Age, sex, school type, grade, and the city they were living in didn't significantly affect depression level $(p>0.05)$. However, depression was more frequent in 12th-grade students (33.3\%) compared with students in 11th-grade or lower $(22.1 \%)$. Factors that significantly affect depression in multivariate analysis are shown in Table 3.

\section{Table 3.}

Multivariate analysis of depression determinants

\begin{tabular}{|c|c|c|c|}
\hline & & OR $(95 \% \mathrm{CI})$ & $p$ value* \\
\hline \multicolumn{2}{|l|}{ Income Level } & $1.00(1.00-1.00)$ & 0.008 \\
\hline \multirow{3}{*}{$\begin{array}{l}\text { Coronavirus risk status } \\
\text { evaluation }\end{array}$} & Thinks that themselves/the household are at risk & $1.94(1.16-3.26)$ & 0.011 \\
\hline & Thinks that relatives/ friends are at risk & $1.88(0.86-4.13)$ & 0.113 \\
\hline & Doesn't know who is at risk in the population & 1 & \\
\hline \multicolumn{2}{|c|}{$\begin{array}{l}\text { Source of information about } \\
\text { coronavirus other than Ministry of } \\
\text { Health/ Healthcare professional }\end{array}$} & $1.95(1.19-3.18)$ & 0.007 \\
\hline \multicolumn{2}{|l|}{ Screen time (hours/day) } & $1.08(1.02-1.15)$ & 0.009 \\
\hline \multicolumn{2}{|c|}{ Mother's coronavirus stress score } & $1.15(1.05-1.25)$ & 0.001 \\
\hline \multicolumn{2}{|c|}{ Family communication score } & $0.81(0.74-0.89)$ & $<0.001$ \\
\hline
\end{tabular}


*Binary logistic regression (age, sex, mother education level, father education level, income level, work loss, coronavirus risk assessment, stay home alone, coronavirus information source, physical exercise, coronavirus case at same home, screen time, mother stress score, father stress score, and family communication score were entered on model)

\section{Level of Trait Anxiety and Affecting Factors}

The median trait anxiety score of the participants was 44.0 (23.0-74.0). Trait anxiety level was higher in girls compared with boys $(p=0.002) ; 12^{\text {th }}$-grade students compared with students at 11 th grade or lower $(p=<0.001)$; students who stayed alone at home usually/ every day compared with students who never stay alone at home $(p=0.032)$; and students who exercised regularly compared with who did not $(p<0.001)$. In addition, trait anxiety was higher in students who thought that themselves or the household are at risk compared with those who didn't know who is at risk in the population and in students who had a coronavirus case at home compared with students who didn't have $(p=0.034)$

\section{Table 4.}

The evaluation of factors that affect STAI-trait anxiety and STAI-state anxiety scores

\begin{tabular}{|c|c|c|c|c|c|}
\hline & & \multicolumn{2}{|l|}{ STAI-trait score } & \multicolumn{2}{|l|}{ STAI-state score } \\
\hline & & $\begin{array}{l}\text { Median } \\
(\text { min-max })\end{array}$ & $p$ value* & $\begin{array}{l}\text { Median } \\
\text { (min-max) }\end{array}$ & $p$ value* \\
\hline \multirow[t]{2}{*}{ Sex } & Female & $44.0(25.0-73.0)$ & 0.002 & $40.0(20.0-78.0)$ & 0.408 \\
\hline & Male & $43.0(23.0-74.0)$ & & $39.0(20.0-77.0)$ & \\
\hline \multirow[t]{2}{*}{ Grade } & $11^{\text {th }}$ grade or below & $42.0(23.0-74.0)$ & $<0.001$ & $38.0(20.0-78.0)$ & $<0.001$ \\
\hline & $12^{\text {th }}$ grade & $46.5(25.0-72.0)$ & & $45.0(20.0-68.0)$ & \\
\hline \multirow{2}{*}{$\begin{array}{l}\text { At least one parent } \\
\text { is a healthcare } \\
\text { professional }\end{array}$} & Yes & $46.0(26.0-67.0)$ & 0.523 & $45.0(27.0-78.0)$ & 0.034 \\
\hline & No & $44.0(23.0-74.0)$ & & $39.0(20.0-77.0)$ & \\
\hline \multirow{3}{*}{$\begin{array}{l}\text { Staying alone at } \\
\text { home }\end{array}$} & I never stay alone at home & $42.0(24.0-73.0)$ & $0.032^{* * *}$ & $37.5(20.0-66.0)$ & $<0.001 * *$ \\
\hline & $\begin{array}{l}\text { I occasionally stay alone } \\
\text { at home }\end{array}$ & $43.0(23.0-72.0)$ & & $39.0(20.0-68.0)$ & \\
\hline & $\begin{array}{l}\text { I generally/every day stay } \\
\text { alone at home }\end{array}$ & $46.0(28.0-74.0)$ & & $48.0(24.0-78.0)$ & \\
\hline \multirow{2}{*}{$\begin{array}{l}\text { Regular physical } \\
\text { exercise }\end{array}$} & Yes & $42.0(24.0-74.0)$ & $<0.001$ & $37.0(20.0-78.0)$ & $<0.001$ \\
\hline & No & $46.0(23.0-72.0)$ & & $43.0(20.0-70.0)$ & \\
\hline \multirow[t]{3}{*}{$\begin{array}{l}\text { Coronavirus risk } \\
\text { status assessment }\end{array}$} & $\begin{array}{l}\text { Thinks that themselves/ } \\
\text { the household are at risk }\end{array}$ & $46.0(26.0-73.0)$ & $0.002 * *$ & $44.0(20.0-78.0)$ & $<0.001$ ** \\
\hline & $\begin{array}{l}\text { Thinks that relatives/ } \\
\text { friends are at risk }\end{array}$ & $42.0(24.0-64.0)$ & & $36.0(20.0-66.0)$ & \\
\hline & $\begin{array}{l}\text { Doesn't know who } \\
\text { is at risk in the population }\end{array}$ & $42.0(23.0-74.0)$ & & $37.0(20.0-77.0)$ & \\
\hline \multirow{2}{*}{$\begin{array}{l}\text { The presence of a } \\
\text { coronavirus case at } \\
\text { home }\end{array}$} & Yes & $49.5(28.0-74.0)$ & 0.034 & $50.0(38.0-77)$ & 0.004 \\
\hline & No & $44.0(23.0-73.0)$ & & $39.0(20.0-78.0)$ & \\
\hline
\end{tabular}

Trait anxiety had a moderate level positive correlation with state anxiety $(r=0.665)$, weak positive correlations with age $(r=0.195)$, screen time $(r=0.152)$, self-rated risk score about coronavirus $(r=0.172)$, mother's coronavirus stress score $(r=0.206)$, and father's coronavirus stress score $(\mathrm{r}=0.143)$, and had a moderate negative correlation with family communication score $(r=-0.367)$.

Table 5.

Multivariate analysis of anxiety determinants
Multivariate analysis of the factors affecting trait anxiety revealed that female gender $(O R=1.5)$, being at $12^{\text {th }}$ grade $(O R=2.20)$, thinking that themselves or the household were at risk $(O R=1.72)$, mother's coronavirus stress score $(O R=1.19)$, and family communication score $(O R=0.73)$ were associated with trait anxiety $(p<0.05)$ 


\begin{tabular}{|c|c|c|c|c|c|}
\hline & & \multicolumn{2}{|l|}{ STAI- trait anxiety } & \multicolumn{2}{|c|}{ STAI- state anxiety } \\
\hline & & OR $(95 \% \mathrm{CI})$ & p value* & $O R(95 \% \mathrm{CI})$ & $p$ value $* *$ \\
\hline \multicolumn{2}{|l|}{ Female sex } & $1.50(1.0-2.25)$ & 0.050 & - & - \\
\hline \multicolumn{2}{|l|}{ Being in $12^{\text {th }}$ grade } & $2.20(1.40-3.46)$ & 0.001 & $1.78(1.11-2.85)$ & 0.015 \\
\hline \multicolumn{2}{|c|}{ Regular physical exercise } & - & - & $1.54(1.01-2.35)$ & 0.043 \\
\hline \multirow[t]{3}{*}{$\begin{array}{l}\text { Coronavirus risk } \\
\text { status assessment }\end{array}$} & $\begin{array}{l}\text { Thinks that themselves/ } \\
\text { the household are at risk }\end{array}$ & $1.72(1.12-2.64)$ & 0.012 & $1.76(1.12-2.76)$ & 0.013 \\
\hline & $\begin{array}{l}\text { Thinks that relatives/ } \\
\text { friends are at risk }\end{array}$ & $1.44(0.75-2.77)$ & 0.270 & $0.76(0.38-1.51)$ & 0.441 \\
\hline & $\begin{array}{l}\text { Doesn't know who is at } \\
\text { risk in the population }\end{array}$ & 1 & & 1 & \\
\hline \multirow{3}{*}{$\begin{array}{l}\text { Staying alone at } \\
\text { home }\end{array}$} & I never stay alone at home & - & - & 1 & \\
\hline & I occasionally stay alone at home & - & - & $1.00(0.64-1.56)$ & 0.970 \\
\hline & $\begin{array}{l}\text { I generally/every day stay alone at } \\
\text { home }\end{array}$ & - & - & $2.15(1.07-4.33)$ & 0.032 \\
\hline \multicolumn{2}{|c|}{ Mother's coronavirus stress score } & $1.19(1.10-1.28)$ & $<0.001$ & $1.13(1.03-1.25)$ & 0.008 \\
\hline \multicolumn{2}{|c|}{ Father's coronavirus stress score } & - & - & $1.16(1.05-1.27)$ & 0.002 \\
\hline \multicolumn{2}{|c|}{ Family communication score } & $0.73(0.67-0.80)$ & $<0.001$ & $0.76(0.70-0.83)$ & $<0.001$ \\
\hline \multicolumn{6}{|c|}{$\begin{array}{l}\text { *Binary logistic regression (age, sex, grade, coronavirus risk assessment, staying alone at home, regular physical exercise, coronavirus case at } \\
\text { same home, screen time, mother's stress score, father's stress score, and family communication score were entered on model) } \\
\text { **Binary logistic regression (age, sex, grade, healthcare professional parent, coronavirus risk assessment, staying alone at home, regular physical } \\
\text { exercise, coronavirus case at same home, screen time, mother's stress score, father's stress score, and family communication score were entered } \\
\text { on model) }\end{array}$} \\
\hline
\end{tabular}

\section{Level of State Anxiety and Affecting Factors}

The median state anxiety score of the participants was 39.0 (20.0-78.0). The median state anxiety score was higher in 12th-grade students compared with $11^{\text {th }}$ or lower grades $(p=<0.001)$; in students who had at least one parent working as a healthcare professional compared with who didn't have $(p=0.034)$; who stayed generally/ every day alone at home compared with who never stayed alone $(p<0.001)$; and who didn't regularly exercise compared with who did $(p<0.001)$.

Also, the median state anxiety score was higher in students who thought themselves or the household were at risk for coronavirus compared with students who didn't know who is at risk in the population; and who had a coronavirus case at home compared with who didn't have a case at home $(p=0.004)$

The median state anxiety score had low-level positive correlations with age $(r=0.197)$, screen time $(r=0.130)$, father's coronavirus stress score $(r=0.274)$, and the number of days from the latest exit from home $(r=0.099)$; moderate level positive correlations with trait anxiety $(r=0.665)$, self-rated coronavirus risk score $(r=0.301)$, and mother's coronavirus stress score $(r=0.326)$ and moderate negative correlation with family communication score $(r=-0.321)$.

Multivariate analysis of the factors that affect state anxiety score revealed that being at $12^{\text {th }}$ grade $(O R=1.78)$, not exercising regularly $(O R=1.54)$, thinking that themselves or the household were at risk $(O R=1.76)$, staying at home alone generally/ every day $(O R=2.15)$, mother's coronavirus stress score $(O R=1.13)$, father's coronavirus stress score $(O R=1.16)$ and family communication score $(O R=0.76)$ were associated with state anxiety $(p<0.05)$

\section{Discussion}

In this cross-sectional study evaluating high school children, the prevalence of depression was $22.9 \%$. A previous study in the same age group reported a similar rate (Ahmed et al., 2020), and several studies reported higher rates (Rios-González and Palacios; Zhou et al., 2020). The lower depression rate we detected in adolescents may be since the participants were completely recruited from those living in the city. Because, in a comprehensive study, the prevalence of depression in children and adolescents living in urban areas was lower than those living in rural regions (Zhou et al., 2020). Also, this may be since $69 \%$ of the participants get information from the correct sources (Ministry of Health and healthcare professionals). The higher knowledge of COVID-19 has been noted as a protective factor against depression (Lei, 2020; C. Wang, Pan, Wan, Tan, Xu, Ho, 2020; Zhou, 2020). In this study, those who received information from the correct sources were less depressed (19.3\%); those who received information from other sources (such as social media, neighbours, friends) were more depressed $(30.9 \%)$. Multivariate analysis revealed that the risk was approximately 2 times higher.

A study from China noted that adolescents had a higher incidence of depressive symptoms during COVID-19 than adults (C. Wang, Pan, Wan, Tan, Xu, Ho, 2020). Similarly, higher rates of depression were found in this study than the rates reported in adults in other studies (Ahmed, 2020; Lei, 2020; G. Wang, 2019).

Expectations and evaluations about the pandemic can affect the mental health of children and adolescents in various ways. For example, having a more pessimistic outlook on the pandemic and having more fear of 
himself/herself or a relative getting infected may cause behavioral changes (Lee, 2020). Being optimistic about the pandemic and not worrying about being infected caused depression scores to decrease (Xie et al., 2020). In this study, the prevalence of depression in those who thought they and their household were more at risk was twice as high as those who did not know who was at risk in society. In addition, self-rated coronavirus risk scores of depressive adolescents were higher than non-depressive adolescents.

Family support plays a vital role in mental health during the pandemic. Having a supportive family can protect many individuals against mental distress (Crawley, 2020). Conversely, it has been shown that adolescents who were left home alone during workdays were more likely to have depression (F. Chen, 2020). Similarly, in this study, more frequent depression $(32.4 \%$ ) was found in children who said they were usually alone at home. In addition, adolescents with depression were found to have lower family communication scores in this study. One of the factors associated with depression in adolescents is low parental education (Lewinsohn, 1994). Similarly, in this study, depression was more common in those with lower parental education.

Stressful events are predisposing factors for psychiatric disorders, particularly depression (Yang, 2015). Children are highly affected by family and social conditions such as family stress, financial problems, and parental psychopathology (Conger, Ge, Elder Jr, Lorenz and Simons, 1994; McLoyd, Jayaratne, Ceballo and Borquez, 1994; Pilowsky, Wickramaratne, Nomura and Weissman, 2006). Consistently, the perceived mother and father stress levels in this study were higher in depressive adolescents.

We couldn't find any difference between depression rate and sex or school grade, which were associated with depression in previous studies. Female sex is a risk factor for depression (F. Chen, 2020; Zhou, 2020), and depression prevalence increases with higher grades in secondary school and high school (Zhou, 2020). There are also studies involving adults or adolescents with contradicting results. Two previous studies found higher depression and stress levels in females (Alvis, Shook and Oosterhoff, 2020; C. Wang, Pan, Wan, Tan, Xu, Ho, 2020), while another study found opposite results (C. Wang, Pan, Wan, Tan, Xu, McIntyre, 2020). Another study (Ahmed et al., 2020) couldn't find a relationship between sex and depression. In this study, no significant relationship was found between depression, neither sex nor grade.

The prevalence of depressive symptoms is significantly affected by socio-cultural and economic factors (Kleinman, 2004). During this period, some families experienced a decrease in income level due to parental work loss associated with the COVID-19 pandemic. In this study, the prevalence of depression was higher among adolescents whose parents lost their works than those who did not ( $34.2 \%$ vs. $21 \%$; respectively). In addition, the income level of the families of adolescents with depression was found to be lower than the group without depression. In a study with adults, economic loss during a pandemic and low household income were associated with depression. In the same study, those who experienced financial loss were more depressed than those who did not, and likewise, depression prevalence was higher in those with lower household income (Lei, 2020). These factors associated with depression may affect children living with parents.

Quarantine increases screen time for many reasons. Children and adolescents use computers to access information due to school closures and for entertainment and social interaction. However, spending a long time in front of the screen may have negative effects on mental health. A study found a positive relationship between depression and screen time (F. Chen, 2020). Supportingly, in this study it is found that children with depression had more screen time than children without.

A positive relationship was found between the COVID-19 pandemic and anxiety (Roy, 2020). Studies with children and adolescents demonstrated higher anxiety symptoms in girls (F. Chen, 2020; Zhou, 2020). In this study, girls were found to have higher trait anxiety scores. In a study with university students in China, women compared to men had higher risk perceptions. Also, having confirmed or suspected COVID-19 cases among the household or friends increased the risk perception (Ding, 2020). In this study, both state and trait anxiety scores were higher in adolescents who had coronavirus cases among the household than those who did not. Also, in this study, both state and trait anxiety scores of adolescents who think that they or their household were at risk were higher. A COVID-19 case among the household is expected to increase the risk of anxiety by increasing the perceived risk level. A study with college students in China concluded that having a relative or acquaintance got COVID-19 increased anxiety prevalence (Cao, 2020). In a study with adults in Turkey, anxiety increased with the belief of an increased probability of catching COVID-19 (Artan, Atak, Karaman and Cebeci, 2020). A previous study conducted during a previous epidemic revealed that knowing a friend or relative was quarantined increased anxiety (Jallon, 2018).

Although the medical literature demonstrated that children are minimally susceptible to COVID-19, one of the groups most affected by the psychosocial impact of the pandemic is children. Especially children whose parents are healthcare workers are at greater risk. During the COVID19 pandemic, closure to homes due to social isolation has provided many parents with the opportunity to spend more time with their children. However, in children whose parents were healthcare workers, this resulted oppositely, even causing some parents not to go home due to concerns about contaminating the household (Q. Chen, 2020). In this study, the state anxiety scale scores were higher in adolescents whose parents were healthcare workers than those whose parents were not. This result may be related to the fear of losing their parents. In addition, spending less time with their parents during this period may also contribute to anxiety.

It has been shown that there is a small to moderate association between anxiety and loneliness or social isolation, and the duration of loneliness is more associated with anxiety than the severity of loneliness (Ginter, Lufi and Dwinell, 1996). In this study, children who stayed alone at home usually or every day had higher anxiety scores. People who spend long periods at home, especially those alone, may be more exposed to negative automatic thoughts. Therefore, they may perceive the COVID-19 threat more severely. During the pandemic period, the closure of schools and the isolation at home, and 
minimization of the activities might have contributed to this situation.

In a study evaluating the relationship between grade and anxiety, as the grade increased in high school, the anxiety symptoms increased (Zhou, 2020). In this study, multivariate analysis revealed that the risk was approximately two times higher for both trait and state anxiety in senior students. In a study conducted on adolescents during the COVID-19 pandemic, anxiety was lower in those who did regular physical exercise (F. Chen, 2020). In this study, those who did not regularly exercise at home during the social isolation period had higher state and trait anxiety scores than those who exercised. Therefore, it is crucial not to interrupt people's lifestyles during social isolation completely and to maintain an active lifestyle at home for both physical and mental health.

In this study, a positive correlation was found between the state and the trait anxiety scores. In Turkey, two studies in the general population (Colgecen and Colgecen, 2020; Goksu and Kumcagiz, 2020) and a study in university students found a moderate correlation between state and trait anxiety scores (Calik, 2020). In one of these studies conducted in the general population, the state anxiety scale score was found to be significantly higher than the trait anxiety scale score (Colgecen and Colgecen, 2020). Because the epidemic is an unexpected event, a higher state anxiety score is anticipated. However, we found a lower level of state anxiety. This may be due to the population included in the study was aware of lower COVID-19 sickness and death rates in young people.

\section{Limitations}

This study has several limitations. The first one is the inclusion of schools in the city center, which mainly represented a population with a higher socioeconomic level. This is an important determinant of psychiatric disease. Second, the fact that the data collection method is an online survey method may be another limitation due to the possibility of the parents to fill the questionnaire. However, it was not appropriate to use the face-to-face survey method in the active pandemic process. The third one was the evaluation of anxiety and depression by selfreport instead of clinical interviews. The strengths of the study were the involvement of two centers, a high acceptance rate $(73 \%)$, and a high target achievement rate $(88 \%)$. In addition, the scarcity of studies on the subject in the world and in Turkey makes this study valuable. This study was performed a period after a curfew was imposed on the adolescent age group and therefore, loneliness and social isolation were at a maximum level which also increases the importance of this study's findings. The pandemic is not over, the extent of the limitations on daily life still fluctuates, and we believe that our work provides valuable insights to develop appropriate policies in this process.

\section{Conclusion}

Our results demonstrated that adolescents suffer from negative psychological impacts during the social isolation in the COVID-19 pandemic. Especially parental factors influence their psychological wellness. İmproving family dynamics and making policies considering the adolescents' mental health are essential measures while addressing COVID-19. Mental health is considered to be the most important factor for good life quality. Mentally healthy adolescents can carry their happiness and self-esteem to adulthood, thereby coping with adversities.

\section{Declarations}

\section{Ethics Approval and Consent to Participate}

Ethics Committee Approval for the present study (Decision Number: 2020/05-14) was obtained from Nigde Omer Halisdemir University Ethics Committee on the date of 01/06/2020. Informed consent of the parents and the students was obtained online before the application of the online questionnaire.

\section{Consent for Publication}

Not applicable.

Availability of Data and Materials

Data sets used and / or analyzed during the study can be obtained from the relevant author upon appropriate request.

\section{Competing Interests}

The authors declare that there is no conflict of interest.

\section{Funding}

Not applicable.

\section{Authors' Contributions}

NY contributed to the planning of the study, data collection, data analysis, and writing of the article. ME contributed to the planning of the study and writing of the article. MO contributed to data collection and article writing. All authors have read and approved the final version of the article.

\section{Acknowledgments}

Not applicable.

\section{References}

Ahmed, M. Z., Ahmed, O., Aibao, Z., Hanbin, S., Siyu, L. and Ahmad, A. (2020). Epidemic of COVID-19 in China and associated Psychological Problems. Asian journal of psychiatry, 102092.

Alvis, L., Shook, N. and Oosterhoff, B. (2020). Adolescents' prosocial experiences during the covid-19 pandemic: Associations with mental health and community attachments.

Artan, T., Atak, I., Karaman, M. and Cebeci, F. (2020). Relationship Between Sociodemographic Characteristics, Psychological Resilience and Anxiety Levels in the Coronavirus (COVID-19) Outbreak. Electronic Turkish Studies, 15(6).

Asmundson, G. J. and Taylor, S. (2020). Coronaphobia: Fear and the 2019-nCoV outbreak. Journal of anxiety disorders, 70, 102196.
Atrooz, F., Liu, H. and Salim, S. (2019). Stress, psychiatric disorders, molecular targets, and more. In Progress in molecular biology and translational science (Vol. 167, pp. 77-105): Elsevier.

Brazendale, K., Beets, M. W., Weaver, R. G., Pate, R. R., TurnerMcGrievy, G. M., Kaczynski, A. T.,von Hippel, P. T. (2017). Understanding differences between summer vs. school obesogenic behaviors of children: the structured days hypothesis. International Journal of Behavioral Nutrition and Physical Activity, 14(1), 100.

Brooks, S. K., Webster, R. K., Smith, L. E., Woodland, L., Wessely, S., Greenberg, N. and Rubin, G. J. (2020). The psychological impact of quarantine and how to reduce it: rapid review of the evidence. The Lancet. 
Calik, M. (2020). Determining The Anxiety And Anxiety Levels Of University Students In The COVID 19 Outbreak. International Journal of Medical Science and Clinical Invention, 7(07).

Cao, W., Fang, Z., Hou, G., Han, M., Xu, X., Dong, J. and Zheng, J. (2020). The psychological impact of the COVID-19 epidemic on college students in China. Psychiatry research, 112934.

Chen, F., Zheng, D., Liu, J., Gong, Y., Guan, Z. and Lou, D. (2020). Depression and anxiety among adolescents during COVID-19: A cross-sectional study. Brain, Behavior, and Immunity.

Chen, Q., Liang, M., Li, Y., Guo, J., Fei, D., Wang, L., . . Li, X. (2020). Mental health care for medical staff in China during the COVID-19 outbreak. The Lancet Psychiatry, 7(4), e15-e16.

Chong, M.-Y., Wang, W.-C., Hsieh, W.-C., Lee, C.-Y., Chiu, N.M., Yeh, W.-C., . . Chen, C.-L. (2004). Psychological impact of severe acute respiratory syndrome on health workers in a tertiary hospital. The British Journal of Psychiatry, 185(2), 127-133.

Colgecen, Y. and Colgecen, H. (2020). Evaluation of Anxiety Levels Arising From Covid-19 Pandemic: The Case of Turkey. Electronic Turkish Studies, 15(4).

Conger, R. D., Ge, X., Elder Jr, G. H., Lorenz, F. O. and Simons, R. L. (1994). Economic stress, coercive family process, and developmental problems of adolescents. Child development, 65(2), 541-561.

Crawley, E., Loades, M., Feder, G., Logan, S., Redwood, S. and Macleod, J. (2020). Wider collateral damage to children in the UK because of the social distancing measures designed to reduce the impact of COVID-19 in adults. BMJ Paediatrics Open, 4(1).

Dalton, L., Rapa, E. and Stein, A. (2020). Protecting the psychological health of children through effective communication about COVID-19. The Lancet Child and Adolescent Health, 4(5), 346-347.

Ding, Y., Du, X., Li, Q., Zhang, M., Zhang, Q., Tan, X. and Liu, Q. (2020). Risk perception of coronavirus disease 2019 (COVID19) and its related factors among college students in China during quarantine. PloS one, 15(8), e0237626.

Duan, L. and Zhu, G. (2020). Psychological interventions for people affected by the COVID-19 epidemic. The Lancet Psychiatry, 7(4), 300-302.

Ginter, E. J., Lufi, D. and Dwinell, P. L. (1996). Loneliness, perceived social support, and anxiety among Israeli adolescents. Psychological reports, 79(1), 335-341.

Goksu, O. and Kumcagiz, H. (2020). Perceived Stress Level and Anxiety Levels in Individuals in Covid-19 Outbreak. Electronic Turkish Studies, 15(4).

Goulia, P., Mantas, C., Dimitroula, D., Mantis, D. and Hyphantis, T. (2010). General hospital staff worries, perceived sufficiency of information and associated psychological distress during the A/H1N1 influenza pandemic. BMC infectious diseases, 10(1), 322.

Hall, R. C., Hall, R. C. and Chapman, M. J. (2008). The 1995 Kikwit Ebola outbreak: lessons hospitals and physicians can apply to future viral epidemics. General hospital psychiatry, 30(5), 446452.

Jalloh, M. F., Li, W., Bunnell, R. E., Ethier, K. A., O'Leary, A., Hageman, K. M., . . . Hersey, S. (2018). Impact of Ebola experiences and risk perceptions on mental health in Sierra Leone, July 2015. BMJ global health, 3(2), e000471.

Kilincel, S., Kilincel, O., Muratdagi, G., Aydin, A. and Usta, M. B. (2020). Factors affecting the anxiety levels of adolescents in home- quarantine during COVID- 19 pandemic in Turkey. Asia- Pacific Psychiatry, e12406.

Kleinman, A. (2004). Culture and depression. New England Journal of Medicine, 351(10), 951-953.
Kovacs, M. (1981). Rating scales to assess depression in schoolaged children. Acta Paedopsychiatrica: International Journal of Child and Adolescent Psychiatry.

Lee, J. (2020). Mental health effects of school closures during COVID-19. The Lancet Child and Adolescent Health, 4(6), 421.

Lei, L., Huang, X., Zhang, S., Yang, J., Yang, L. and Xu, M. (2020). Comparison of prevalence and associated factors of anxiety and depression among people affected by versus people unaffected by quarantine during the COVID-19 epidemic in southwestern China. Medical Science Monitor: International Medical Journal of Experimental and Clinical Research, 26,e924609-924601.

Lewinsohn, P. M., Roberts, R. E., Seeley, J. R., Rohde, P., Gotlib, I. H. and Hops, H. (1994). Adolescent psychopathology: II. Psychosocial risk factors for depression. Journal of abnormal psychology, 103(2), 302.

Loades, M. E., Chatburn, E., Higson-Sweeney, N., Reynolds, S., Shafran, R., Brigden, A., . . . Crawley, E. (2020). Rapid Systematic Review: The Impact of Social Isolation and Loneliness on the Mental Health of Children and Adolescents in the Context of COVID-19. Journal of the American Academy of Child and Adolescent Psychiatry.

Malay, D. S. (2020). COVID-19, Pandemic, and Social Distancing. The Journal of Foot and Ankle Surgery, 59(3), 447.

McLoyd, V. C., Jayaratne, T. E., Ceballo, R. and Borquez, J. (1994). Unemployment and work interruption among African American single mothers: Effects on parenting and adolescent socioemotional functioning. Child development, 65(2), 562-589.

Oner, N. and Le Compte, A. (1998). State-Trait Anxiety Inventory Handbook. 2nd Edition, Boğaziçi University Publications, Istanbul.

World Health Organization (2020). WHO Director-General's remarks at the media briefing on 2019-nCoV on 11th February 2020. World Health Organization, Geneva. Available via https://www.who.int/dg/speeches/detail/who-director-general-sremarks-at-the-media-briefing-on-2019-ncov-on-11-february2020. Accessed, 10.

Oy, B. (1991). Childhood Depression Rating Scale: Application to Healthy Children and Children Consulting to Child Mental Health Clinic. Turkish Journal of Psychiatry, 2(2), 137-140.

Pilowsky, D. J., Wickramaratne, P., Nomura, Y. and Weissman, M. M. (2006). Family discord, parental depression, and psychopathology in offspring: 20-year follow-up. Journal of the American Academy of Child and Adolescent Psychiatry, 45(4), $452-460$.

Purgato, M., Gastaldon, C., Papola, D., Van Ommeren, M., Barbui, C. and Tol, W. A. (2018). Psychological therapies for the treatment of mental disorders in low- and middle- income countries affected by humanitarian crises. Cochrane database of systematic reviews (7).

Rios-González, C. M. and Palacios, J. M. Symptoms of Anxiety and depression during the outbreak of COVID-19 in Paraguay.

Roy, D., Tripathy, S., Kar, S. K., Sharma, N., Verma, S. K. and Kaushal, V. (2020). Study of knowledge, attitude, anxiety and perceived mental healthcare need in Indian population during COVID-19 pandemic. Asian journal of psychiatry, 102083.

Rubin, G. J. and Wessely, S. (2020). The psychological effects of quarantining a city. BMJ, 368

Spielberger, C. D. (2010). State- Trait anxiety inventory. The Corsini encyclopedia of psychology, 1-1.

Taylor, S. (2019). The psychology of pandemics: Preparing for the next global outbreak of infectious disease: Cambridge Scholars Publishing.

Tsamakis, K., Rizos, E., Manolis, A. J., Chaidou, S., Kympouropoulos, S., Spartalis, E., .. . Triantafyllis, A. S. (2020). 
[Comment] COVID-19 pandemic and its impact on mental health of healthcare professionals. Experimental and Therapeutic Medicine, 19(6), 3451-3453.

Wang, C., Pan, R., Wan, X., Tan, Y., Xu, L., Ho, C. S. and Ho, R. C. (2020). Immediate psychological responses and associated factors during the initial stage of the 2019 coronavirus disease (COVID-19) epidemic among the general population in China. International journal of environmental research and public health, 17(5), 1729

Wang, C., Pan, R., Wan, X., Tan, Y., Xu, L., McIntyre, R. S., Sharma, V. K. (2020). A longitudinal study on the mental health of general population during the COVID-19 epidemic in China. Brain, Behavior, and Immunity.

Wang, G., Zhang, J., Lam, S. P., Li, S. X., Jiang, Y., Sun, W., Li, S. (2019). Ten-year secular trends in sleep/wake patterns in Shanghai and Hong Kong school-aged children: a tale of two cities. Journal of Clinical Sleep Medicine, 15(10), 1495-1502.
Xiang, Y.-T., Yang, Y., Li, W., Zhang, L., Zhang, Q., Cheung, T. and Ng, C. H. (2020). Timely mental health care for the 2019 novel coronavirus outbreak is urgently needed. The Lancet Psychiatry, 7(3), 228-229.

Xie, X., Xue, Q., Zhou, Y., Zhu, K., Liu, Q., Zhang, J. and Song, R. (2020). Mental health status among children in home confinement during the coronavirus disease 2019 outbreak in Hubei Province, China. JAMA pediatrics.

Yang, L., Zhao, Y., Wang, Y., Liu, L., Zhang, X., Li, B. and Cui, R. (2015). The effects of psychological stress on depression. Current neuropharmacology, 13(4), 494-504.

Zhou, S.-J., Zhang, L.-G., Wang, L.-L., Guo, Z.-C., Wang, J.-Q., Chen, J.-C., . . . Chen, J.-X. (2020). Prevalence and sociodemographic correlates of psychological health problems in Chinese adolescents during the outbreak of COVID-19. European Child and Adolescent Psychiatry, 1-10. 